\title{
Impact of SHGs on a Particularly Vulnerable Tribe (The Chenchus)
}

\author{
B. Seetharamaiah \\ Ph.D. Research Scholar, Department of Economics \\ Sri Venkateswara University
}

\begin{abstract}
The chenchus are a primitive Tribal group inhabiting Nallamala forests of Andhra Pradesh and Telangana. The livelihoods of the tribal group are based on primitive agriculture and forestry. The social development indicators of the country with very high levels of illiteracy, high MMR, IMR and high morbidity rate, the chenchus are a declaiming tribe in terms of population. Sustained efforts made by the government of Andhra Pradesh have resulted in the mobilization of these households into SHGs. This paper deals with how multiple interventions implemented through SHGs have impacted the livelihoods of the Chenchus. The SHG model has contributed significantly to the assets, income, consumption, housing and empowerment of the Chenchus. This study covering a sample of 106 chenchu households and drawn from 16 SHGs from 4 districts was conducted as part of Ph.D. work during 2014-2015.The study establishes the sustainability of SHG approach to the development of Tribal communities.
\end{abstract}

\section{INTRODUCTION}

The Chenchus are an aboriginal tribe of the central hill regions of erstwhile combined state of Andhra Pradesh, spread over the six districts of Kurnool, Prakasam, Mahabubnagar, Guntur, Nalgonda and Ranga Reddy. The 121,000 strong Chenchu tribal households, who are spread across six districts, are considered among the poorest of the poor. The Chenchus are referred to as one of the Primitive Tribal Groups (now called particularly vulnerable tribes) that is still dependent on forests and do not prefer to cultivate land but hunt for a living, although the government has allotted them substantial extent of land for cultivation. However, consequent on reserving vast tracts of Nallamala forest and reserving a part of it as Wild life reserve, the livelihoods of the Chenchus have been affected. The Chenchus have responded unenthusiastically to other government efforts to induce them to resettle and take-up other activities.

The Government of Andhra Pradesh (GoAP) has implemented SHG-centered development programme for the Chenchus under its flagship programme of Velugu (earlier called Indira Kranthi Patham). However, SHGs and federations of Chenchus promoted during 2001-2009 did not produce the desired results. Most of the SHGs and VOs became dormant and there was no perceptible improvement in the livelihoods of the Chenchus. The GOAP then adopted a comprehensive development plan for the Chenchus, but within the SHG and federation framework with effect from 2008. Instead of mobilizing the Chenchus into mixed SHGs, exclusive institutions of the Chenchus were promoted and provided support. This has had a significant impact on certain aspects of Chenchu livelihoods. An attempt is made in this paper to assess the impact of Chenchu-SHG development initiatives implemented by the erstwhile GOAP under its Velugu programme from April 2009 to March 2013.

\section{NEW CHENCHU DEVELOPMENT INITIATIVES}

Given the thin scatter of their habitations in the remote and interior areas of Nallamala forests, mobilizing them into the SHG framework and initiate development activities proved to be a formidable task in the initial years. Despite several efforts, the SHGs and federations of the Chenchus (along with others in some cases) remained dormant and their livelihoods could not be promoted in a sustained manner. It was in this context that the GOAP (through Society for Elimination of Rural Poverty-SERP) designed a special Chenchu Development package encompassing the Chenchus in 17 mandals of 4 districts within the overall project framework to promote: 


\section{B. Seetharamaiah}

- functionally effective SHGs, exclusive VOs and MSs of the Chenchus;

- sustainable NTFP/forest based livelihoods of the Chenchus;

- food security of the Chenchus through a food credit line with part of the funds dovetailed from the community grain bank scheme of the GOI;

- investments in a range of income generating assets through CIF and bank linkage; and

- comprehensive social development activities including health (nutrition centers and CHWs) housing (bridge financing), education (loans) and sanitation (ISLs) initiatives.

\section{OBJECTIVES OF THE STUDY}

The Chenchu development initiatives had been implemented from April 2009 to March 2013 involving investment of substantial amount of resources through the SHGs and their federations. These funds were meant for promoting food security, livelihoods and social development of the Chenchus. In view of the substantial amount of resources invested in the development of Chenchus through their SHGs, the present study seeks to assess the impact of these initiatives on the Chenchus.

The objective of the study is to assess the impact of Chenchu development initiatives undertaken during 2009-13 on the Chenchu households. More particularly, the objectives of the study were:

- to assess the impact of Chenchu initiatives development on the functioning of Chenchu SHGs;

- to analyze the impact on savings, internal borrowing, loans utilized and repaid, grants received and utilized;

- to examine the access of Chenchu SHGs to bank loans and their utilization and repayment;

- to assess the access of Chenchus to CIF for livelihoods, health, education, housing and home needs;

- to assess the impact of initiatives on household assets, income and such other parameters; and

- to examine the contribution of Chenchu SHGs to the empowerment of women.

\section{SAMPLe Details}

A multi-stage random sampling method was adopted to identify sample households from the four Chenchu districts of Kurnool, Prakasam, Guntur and Mahabubnagar. Four representative MSs were selected. These were Atmakur, Pullalacheruvu, Durgi and Balmur. From each MS, two VOs were chosen on a representative basis. Thus, 8 VOs were selected at the third stage. From each VO, two representative sample SHGs were chosen later. From each SHG, 6 to 7 members and their households were selected for intensive study. Thus, a total of 106 households were selected and detailed data collected on various aspects. The sample details are presented in the Tables-1 \& 2. The focus of the study is on tracking the perceived difference between the pre and post intervention situation as described by the sample households during April 2009 - March 2013. The study was conducted during 2014-15 as part of a Ph.D. research project.

Table1. Size and Distribution of Sample SHGs

\begin{tabular}{|l|l|l|l|}
\hline S. No. & District-Mandal & Names of Villages & No. of Sample SHGs \\
\hline 1. & Prakasam - Pullalacheruvu & $\begin{array}{l}\text { - Garapenta } \\
\text { - Chennapalem }\end{array}$ & 4 \\
\hline 2. & Guntur - Durgi & $\begin{array}{l}\text { - Terala } \\
\text { - Raja Nagar }\end{array}$ & 4 \\
\hline 3. & Kurnool - Atmakur & $\begin{array}{l}\text { - Indreswara Gudem } \\
\text { - Nagaluty Gudem }\end{array}$ & 4 \\
\hline 4. & Mahabubnagar - Balmur & $\begin{array}{l}\text { - Chenchu Ggudem } \\
\text { - Gudibanda }\end{array}$ & 4 \\
\hline 5. & Total & & 16 \\
\hline
\end{tabular}

Table2. Size and Distribution of Sample Households

\begin{tabular}{|l|l|l|l|}
\hline S. No. & District-Mandal & No. of Sample Households & Percentage to Total Sample HHs \\
\hline 1. & Prakasam-Pullalacheruvu & 25 & 24 \\
\hline 2. & Guntur-Durgi & 29 & 27 \\
\hline 3. & Kurnool-Atmakur & 24 & 23 \\
\hline 4. & Mahabubnagar-Balmur & 28 & 26 \\
\hline 5. & Total & 106 & 100 \\
\hline
\end{tabular}




\section{SAMPle Characteristics}

All sample households belong to the Chenchu community, a primitive tribal group. All except one sample household were Hindus in terms of religious belief. All belong to BPL category of households. The Chenchu families were predominantly nuclear in nature. In the sample, $87 \%$ were nuclear families and the rest joint families. There were no extended families. The average size of the sample households was $<5$. The average age of the sample women respondents was 5.5 years. About $80 \%$ of the respondents were either illiterate or neo-literate. However, the relatively young male members of the households had primary or upper primary school level education. The main occupation for the Chenchu households was agriculture, agricultural labour and collection of minor forest produce. Sample households had access to agriculture land, which was either assigned by the government or under the possession of the households without a valid title. The agriculture was largely subsistence oriented. The principal crops grown were paddy, groundnut, green gram, red gram, Bengal gram, castor and plantation crop of mango. Being largely rain-fed, the productivity of crops was very low, despite the support from ITDA. The Chenchus faced recurrent risks arising from production and price uncertainties for the crops grown. In order to supplement household income, the Chenchus also depended on collection of minor forest produce and hunting, which were once their primary source of livelihood. With the emergence of MGNREGS, wage income had become a significant supplementary source of livelihood for several households. A majority of the sample households indicated NREGS as secondary source of livelihood.

\section{BENEFITS RECEIVED FROM CHENCHU CBOS}

\subsection{Duration of SHG Membership}

The 16 sample SHGs selected had an average age of 8.5 years, with the oldest being 13 years of age and the youngest 4 years of age. The average duration of membership of the sample beneficiaries is also 8.5 years. The period is long enough to capture the developmental impact of the Chenchu initiatives since 2009.

\subsection{Saving}

One of the principal benefits expected of the SHG is to promote member savings. Adherence to regular saving norm and the amount saved are an indication of the impact of the CBO on the members. Of the 16 sample SHGs, 10 were saving regularly as per the agreed norms. The monthly saving norm varied between Rs.30/- and Rs.100/- per person. The cumulative amount of saving per sample member at the end of Mar.'13 stood at Rs.2,920/-. However, there was a great deal of disparity between members in different SHGs. The cumulative saving was as high as Rs.4,797/- per member at the end of Mar.'13 for some members. The amounts could have been higher if some SHGs had not adopted the undesirable practice of distributing corpus among members at frequent intervals. Notwithstanding such limitations, the SHG membership facilitated regular savings by members which is the basis for borrowing from the corpus.

\subsection{Internal Loans Accessed}

Poor access to credit markets has subjected the Chenchus to multiple types of exploitation by the trader-financiers. The practice of taking tied loans from informal market at high rates of interest with unfavourable produce buyback arrangements has kept the Chenchus in perpetual poverty. Creating access to SHG internal loans is an attempt to break this vicious circle of poverty. The advantage with the internal loan facility is that it can be accessed at very short notice from the CBO at low rates of interests and without having to produce any security. The other advantage with the internal borrowing is that it can be accessed multiple times subject to the conditions laid down by the SHGs for this purpose. Thus, it can be observed that some members borrowed multiple times depending on their need and availability of funds. The sample household data furnished in Table-3 indicates that each sample member on the average was able to borrow Rs.4,518/- from the SHG's own funds at $12 \%$ rate of interest. This is a significant contribution to the Chenchus facing severe credit constraint. However, only $41 \%$ of the members borrowed from the SHG corpus. The number of borrowers needs to be increased by preventing corpus sharing practices and minimizing the overdue repayments. 
Table3. Amount of Internal Loans Received by Sample Members

\begin{tabular}{|l|l|l|l|l|l|l|l|l|} 
In Rs. \\
\begin{tabular}{|l} 
S. \\
No.
\end{tabular} & District & First Time & Second Time & \multicolumn{2}{l|}{ Third Time } & $\begin{array}{l}\text { Total } \\
\text { Amount }\end{array}$ \\
\cline { 3 - 9 } & Amount & $\begin{array}{l}\text { Out- } \\
\text { standing }\end{array}$ & Amount & $\begin{array}{l}\text { Out- } \\
\text { standing }\end{array}$ & Amount & $\begin{array}{l}\text { Out- } \\
\text { standing }\end{array}$ & \\
\hline 1. & Prakasam & 82250 & 46746 & 27125 & 0 & 8750 & 8750 & 118125 \\
\hline 2. & Guntur & 79625 & 51188 & 20913 & 1355 & 25160 & 17500 & 125697 \\
\hline 3. & Kurnool & 2450 & 2450 & 0 & 0 & 0 & 0 & 2450 \\
\hline 4. & $\begin{array}{l}\text { Mahabub- } \\
\text { Nagar }\end{array}$ & 62248 & 43575 & 27125 & 9625 & 4375 & 0 & 93748 \\
\hline
\end{tabular}

\section{ACCESS TO BANK LOAN}

Bank loan is a significant source of credit to the members. The sample data indicates that $59 \%$ of the members had accessed bank loan at an average rate of Rs.15,120/- per person. The highest average loan amount was accessed in Guntur (Rs.22,467/-) followed by Prakasam (Rs.19,444/-). The lowest amount of loan was observed in Mahabubnagar (Rs.3,500/-). Some beneficiaries accessed bank loan more than once. The inter-district disparities point to the need for making additional efforts to step-up bank loans, which is emerging as a principal alternative to CIF. It is only through sustained bank linkage effort that the economic status of the sample households can be improved.

Table4. Bank Loan Received (In Rs.)

\begin{tabular}{|l|l|l|l|l|l|l|}
\hline $\begin{array}{l}\text { S. } \\
\text { No. }\end{array}$ & Category & $\begin{array}{l}\text { \% of Members } \\
\text { Received Bank } \\
\text { Loan }\end{array}$ & $\begin{array}{l}\text { Amount } \\
\text { Received - } \\
\text { First Time }\end{array}$ & $\begin{array}{l}\text { Amount } \\
\text { Received - } \\
\text { Second Time }\end{array}$ & Total & $\begin{array}{l}\text { Average } \\
\text { Loan Size } \\
\text { per Member }\end{array}$ \\
\hline 1. & Prakasam & 63 & 140000 & 35000 & 175000 & 19444 \\
\hline 2. & Guntur & 138 & 339787 & 176978 & 516765 & 22467 \\
\hline 3. & Kurnool & 175 & 173250 & 63000 & 236250 & 9844 \\
\hline 4. & Mahabubnagar & 44 & 24500 & 0 & 24500 & 3500 \\
\hline 5. & Total & 103 & 677537 & 274978 & 952515 & 15120 \\
\hline
\end{tabular}

\section{REPAYMENT OF BANK LOANS}

The members had a tendency to repay the bank loans as per schedule in order to be eligible for further loans. Thus, among the 158 loans advanced to the sample beneficiaries $84 \%$ of the loans were either fully paid or being repaid as per schedule. The proportion of loans being repaid irregularly is relatively small.

Table5. Repayment Status of Bank Loans

\begin{tabular}{|l|l|l|l|l|l|l|}
\hline S. No. & Category & Prakasam & Guntur & Kurnool & Mahabub-Nagar & Total \\
\hline 1. & Not Repaid & 0 & 0 & 4 & 0 & 4 \\
\hline 2. & Fully Repaid & 16 & 25 & 32 & 12 & 84 \\
\hline 3. & Being Repaid as per & 0 & 23 & 26 & 0 & 49 \\
\hline 4. & Irregular Repayment & 2 & 18 & 2 & 0 & 21 \\
\hline 5. & Total & 18 & 65 & 63 & 12 & 158 \\
\hline
\end{tabular}

\section{ACCESS TO CIF (LIVELIHOOD)}

The principal contribution of the project to the livelihoods of the Chenchus is the access it has provided to CIF loans for undertaking diversification and deepening of livelihood assets. Of the 106 sample beneficiaries, 63 members were able to access the CIF for livelihoods at an average rate of Rs.38,136/- per person. The rate of interest charged on CIF (livelihoods) was 6\%, which was the lowest compared to any other source. However, interest subsidy is provided on bank loans, if the loans are repaid according to schedule. CIF is the largest amount of financial support accessed from any source. However, the other members of the sample did not access CIF livelihoods, but some of them had accessed CIF (food security, health, education, housing and home needs). It is interesting to observe that the beneficiaries from Mahabubnagar received highest average per capita amount of Rs.56,131/- followed by Kurnool (Rs.40,640/-), Prakasam (Rs.26,999/-) and Guntur (Rs.21,000/-). The districts which had recorded lowest per capital bank loan viz., Mahabubnagar and Kurnool received relatively high CIF. Thus, there is a built in element of equity in the distribution of CIF. 
Table6. CIF/Livelihood Fund Received

\begin{tabular}{|l|l|l|l|l|l|l|l|l|l|}
\hline $\begin{array}{l}\text { S. } \\
\text { No }\end{array}$ & District & First Time & Second Time & Third Time & $\begin{array}{l}\text { Total } \\
\text { Amount }\end{array}$ & $\begin{array}{l}\text { Total Out- } \\
\text { standing }\end{array}$ \\
\cline { 2 - 11 } & Amount & $\begin{array}{l}\text { Out- } \\
\text { standing }\end{array}$ & Amount & $\begin{array}{l}\text { Out- } \\
\text { standing }\end{array}$ & Amount & $\begin{array}{l}\text { Out- } \\
\text { standing }\end{array}$ & & \\
\hline 1. & Prakasam & 298499 & 71153 & 121749 & 40084 & 38749 & 23021 & 458997 & 134258 \\
\hline 2. & Guntur & 225750 & 142450 & 26250 & 21875 & 0 & 0 & 252000 & 164325 \\
\hline 3. & Kurnool & 129500 & 109156 & 299460 & 170966 & 140000 & 96996 & 568960 & 377118 \\
\hline 4. & $\begin{array}{l}\text { Maha- } \\
\text { bubnagar }\end{array}$ & 604625 & 434348 & 280000 & 68273 & 238000 & 70320 & 1122625 & 572941 \\
\hline 5. & Total & 1258374 & 757108 & 727459 & 301198 & 416749 & 190337 & 2402582 & 1248643 \\
\hline
\end{tabular}

Table7. CIF/Livelihood Fund Received

\begin{tabular}{|l|l|l|l|l|l|l|l|l|}
\hline $\begin{array}{l}\text { S. } \\
\text { No. }\end{array}$ & District & $\begin{array}{l}\text { Sample } \\
\text { Size }\end{array}$ & $\begin{array}{l}\text { No. of } \\
\text { Members } \\
\text { Received } \\
\text { Loans for } \\
\text { LH }\end{array}$ & $\begin{array}{l}\text { No. of } \\
\text { Loans }\end{array}$ & $\begin{array}{l}\text { \% of } \\
\text { Members } \\
\text { Received } \\
\text { LH Loans }\end{array}$ & $\begin{array}{l}\text { Total } \\
\text { Amount }\end{array}$ & $\begin{array}{l}\text { Average } \\
\text { Loan } \\
\text { Received } \\
\text { Per } \\
\text { Member }\end{array}$ & $\begin{array}{l}\text { Average } \\
\text { Loan } \\
\text { Outstanding } \\
\text { Per Member }\end{array}$ \\
\hline 1. & Prakasam & 25 & 30 & 44 & 119 & 458997 & 26999 & 13424 \\
\hline 2. & Guntur & 29 & 21 & 21 & 72 & 252000 & 21000 & 18258 \\
\hline 3. & Kurnool & 24 & 25 & 42 & 102 & 568960 & 40640 & 29010 \\
\hline 4. & Mahabub-Nagar & 28 & 35 & 56 & 124 & 1122625 & 56131 & 28646 \\
\hline 5. & Total & 106 & 110 & 163 & 103 & 2402582 & 38136 & 24012 \\
\hline
\end{tabular}

\section{REPAYMENT STATUS OF CIF (LIVELIHOODS)}

Most of the sample beneficiaries of CIF were regular in their repayment. It is interesting to note that $63 \%$ of the sample beneficiaries had either repaid fully or repaying as per schedule along with interest charges. The remaining 37\% of the beneficiaries were either not repaying as per schedule or had not started their repayments. A portion of the not repaid component of the CIF loans could be over dues. Notwithstanding the high percentage of repayments, there is scope for improving repayment of CIF as per schedule, such that the funds can be advanced to other uncovered beneficiaries.

Table8. CIF/Livelihood Fund (Repayment Status)

\begin{tabular}{|l|l|l|l|l|l|l|}
\hline S. No. & Category & Prakasam & Guntur & Kurnool & Mahabub-Nagar & Total \\
\hline 1. & Not repaid & 0 & 0 & 11 & 7 & 18 \\
\hline 2. & Fully repaid & 21 & 5 & 9 & 18 & 53 \\
\hline 3. & $\begin{array}{l}\text { Being repaid as per } \\
\text { Schedule }\end{array}$ & 19 & 5 & 11 & 14 & 49 \\
\hline 4. & Irregular repayment & 4 & 11 & 12 & 18 & 44 \\
\hline 5. & Total & 44 & 21 & 42 & 56 & 163 \\
\hline
\end{tabular}

\section{Status of Assets Procured With CIF SuPPORT (LiVEliHOODS)}

It is gratifying to note that about $80 \%$ of the assets procured with CIF support were intact. The assets were held intact by most of the beneficiaries in all sample districts. Assets here include livestock assets such as sheep, goat, milch cattle and buffaloes as well as other assets such as bore wells, engines and other movable assets. Only a small proportion of the beneficiaries reported that they did not possess the assets either due to death of the animal or theft. Some were able to replace the assets, but admitted to not replacing the asset.

Table9. CIF/Livelihood Fund (Asset Status)

\begin{tabular}{|l|l|l|l|l|l|l|}
\hline S. No. & Category & Prakasam & Guntur & Kurnool & Mahabub-Nagar & Total \\
\hline 1. & Asset not procured & 2 & 2 & 0 & 5 & 9 \\
\hline 2. & Asset intact & 33 & 16 & 35 & 46 & 130 \\
\hline 3. & Asset sold and not replaced & 4 & 4 & 4 & 2 & 12 \\
\hline 4. & Asset dead and not replaced & 4 & 0 & 4 & 2 & 9 \\
\hline 5. & Asset replaced & 2 & 0 & 0 & 2 & 4 \\
\hline 6. & Total & 44 & 21 & 42 & 56 & 163 \\
\hline
\end{tabular}




\section{CIF-Health Fund}

The other major benefit from CIF was the borrowing for meeting health related expenditure at a concessional interest rate of $3 \%$. However, only 21 out of 106 sample members had availed the loan for health purposes. The average amount borrowed per member was Rs.11,485/-, with Prakasam accounting highest per capita of Rs.22,167/- followed by Kurnool. It is important to note that there appeared to be certain amount of diversion of CIF borrowed for health purposes, although the VOs granting the CIF loan did take into account the actual medical requirements. It was found that the VOs were granting the loan only after examining the medical records. The health CIF is a unique facility as it provides access to community based support for health emergencies. This is an addition to CIF being allocated for H-N mandals. The repayment of health CIF was also encouraging as only three members could not repay the loan due to family emergencies. All others had either repaid fully or partially.

Table10. Benefits Received from CIF-Health Fund

\begin{tabular}{|l|l|l|l|l|l|l|l|}
\hline $\begin{array}{l}\text { S. } \\
\text { No. }\end{array}$ & District & $\begin{array}{l}\text { Sample } \\
\text { Size }\end{array}$ & $\begin{array}{l}\text { Members } \\
\text { Availing } \\
\text { Health Fund }\end{array}$ & $\begin{array}{l}\text { \% of } \\
\text { Members }\end{array}$ & Amount & $\begin{array}{l}\text { Average } \\
\text { Per Member }\end{array}$ & $\begin{array}{l}\text { Total Loan } \\
\text { Outstanding }\end{array}$ \\
\hline 1. & Prakasam & 25 & 5 & 21 & 66500 & 22167 & 30625 \\
\hline 2. & Guntur & 29 & 7 & 25 & 31500 & 7875 & 11463 \\
\hline 3. & Kurnool & 24 & 2 & 7 & 17500 & 17500 & 17500 \\
\hline 4. & $\begin{array}{l}\text { Mahabub- } \\
\text { nagar }\end{array}$ & 28 & 7 & 25 & 22313 & 5579 & 5672 \\
\hline 5. & Total & 106 & 21 & 19 & 137813 & 11485 & 65259 \\
\hline
\end{tabular}

\section{CIF-HOUSING FUND}

Housing was another purpose for which loans were available for beneficiaries from CIF. The subsidized housing program viz., IAY/Indiramma required the individual beneficiary households to supplement a part of the resources required in the form of contribution. However, the poor Chenchus were not able to mobilize required amounts towards contribution. Further, as payments were made at several stages of construction, the beneficiaries required certain initial advance amount to facilitate construction. The CIF-housing fund was a response to meet such requirements. Out of the 106 sample beneficiaries, 11 reported to have borrowed about Rs.157,500/- from the CIF-housing fund at an average rate of Rs.14,318/-. Two members are reported to have delayed the repayments in Guntur district, while others were making the payments. The sample members have indicated that this facility has freed them from high cost borrowing. But for this facility, they would have borrowed from informal sources at high rates of interest.

Table11. Benefits Received from Housing Fund

\begin{tabular}{|l|l|l|l|l|l|l|l|}
\hline $\begin{array}{l}\text { S. } \\
\text { No. }\end{array}$ & Name of the & District & $\begin{array}{l}\text { No. of Members } \\
\text { Availed } \\
\text { Home Loans }\end{array}$ & \multirow{2}{*}{$\begin{array}{l}\text { Amount } \\
\text { In Rs. }\end{array}$} & & Repayment Status & Outstanding \\
\cline { 5 - 8 } & & & & Fully & Partially & $\begin{array}{l}\text { Not } \\
\text { Repaid } \\
\text { In Rs. }\end{array}$ \\
\hline 1. & Prakasam & 2 & 52500 & 2 & 0 & 0 & 0 \\
\hline 2. & Guntur & 5 & 43750 & 0 & 2 & 4 & 42000 \\
\hline 3. & Kurnool & 4 & 61250 & 0 & 4 & 0 & 60288 \\
\hline 4. & Mahabubnagar & 0 & 0 & 0 & 0 & 0 & 0 \\
\hline 5. & Total & 11 & 157500 & 2 & 5 & 4 & 102288 \\
\hline
\end{tabular}

\section{CIF-HOME NEEDS}

Borrowing for the purpose of meeting home needs is a common requirement among the Chenchus. This includes borrowing for meeting expenditure on life cycle rituals, repayment of old debt and release of mortgaged land and other assets. The CIF also responded to such home needs of the Chenchus by creating a sub-facility under the CIF. Thus, 17 out of 106 beneficiaries had availed loans for home needs at an average rate of Rs.6,370/- per member. Seven borrowers had either fully or partly repaid the loan and only one had an overdue amount. This is another intervention that has minimized the dependence of the Chenchu households on high cost informal credit. In view of the extensive need for consumption loans, the size of the facility could be enhanced and the individual amounts lowered such that a larger number of members can be covered. 
Table12. Benefits Received from Home Needs

\begin{tabular}{|c|c|c|c|c|c|c|c|}
\hline \multirow{2}{*}{$\begin{array}{l}\text { S. } \\
\text { No. }\end{array}$} & \multirow{2}{*}{$\begin{array}{l}\text { Name of the } \\
\text { District }\end{array}$} & \multirow{2}{*}{$\begin{array}{l}\text { Members } \\
\text { Availing Loans } \\
\text { for Home } \\
\text { Needs }\end{array}$} & \multirow{2}{*}{$\begin{array}{l}\text { Amount } \\
\text { In Rs. }\end{array}$} & \multicolumn{3}{|c|}{ Repayment Status } & \multirow{2}{*}{$\begin{array}{l}\text { Outstanding } \\
\text { Amount } \\
\text { In Rs. }\end{array}$} \\
\hline & & & & Fully & Partially & $\begin{array}{l}\text { Not } \\
\text { Repaid }\end{array}$ & \\
\hline 1. & Prakasam & 11 & 90125 & 4 & 7 & 0 & 75250 \\
\hline 2. & Guntur & 2 & 7000 & 2 & 0 & 0 & 0 \\
\hline 3. & Kurnool & 2 & 8750 & 0 & 0 & 2 & 8750 \\
\hline 4. & Mahabubnagar & 2 & 2417 & 2 & 0 & 0 & 0 \\
\hline 5. & Total & 17 & 108292 & 8 & 7 & 2 & 84000 \\
\hline
\end{tabular}

\section{Household Level Changes}

\subsection{Asset Purchase}

One of the significant changes observed in the Chenchu households is in terms of asset diversification. Apart from Velugu, MGNREGS, ITDA, SGSY and the Forest Rights Act have resulted in certain important improvements to their asset holding. The total dry land under the possession of the tribal families recorded an absolute increase of 98 acres in respect of 25 sample members. While the change in the asset holding is due to changes made to the Forest Act, the contribution of Velugu was in terms of enabling the eligible member households to apply for issue of appropriate titles. Further, it was also observed that in respect of 3 members in Mahabubnagar district, there was an increase in the holding of wet land by 5 acres. This was made partly possible by Velugu through its CIF support for improving irrigation facility. ITDA had also provided part assistance towards energisation of the bore wells. In fact, irrigation holds a good deal of potential for development in respect of certain other farmers as well. However, convergent action is required on the part of several agencies to provide multiple types of assistance for this purpose. For example, support is required for drilling bore well, pump sets, energisation, land leveling and development etc.

Table13. Change in the Household Asset Status (Dry Land): Sample

\begin{tabular}{|l|l|l|l|l|l|}
\hline S. No. & District & Before Velugu & Now with Velugu & \multicolumn{2}{l|}{ Change in Land Holding } \\
\cline { 5 - 7 } & & & & Acres & No. of Members \\
\hline 1. & Prakasam & 87 & 111 & 36 & 11 \\
\hline 2. & Guntur & 16 & 16 & 0 & 0 \\
\hline 3. & Kurnool & 35 & 99 & 96 & 20 \\
\hline 4. & Mahabubnagar & 44 & 54 & 15 & 8 \\
\hline 5. & Total & 182 & 280 & 147 & 39 \\
\hline
\end{tabular}

\subsection{Change in Movable Assets: Livestock}

Improvement in livestock assets was reported by a large number of households. Prior to Velugu, the 106 sample households had only 21 heads of milch cattle. Now with more than 5 years of Velugu support through CIF and bank linkage, the number of milch cattle increased to 73 in Mar.'13. The beneficiaries attributed the improvement in milch cattle stock to CIF, ITDA support and bank linkage. However, the members indicated that there is no milk collection infrastructure in the tribal villages, affecting the viability of the household dairy. The project may explore the possibility of setting up bulk milk cooling centers or linking the villages to the existing dairy infrastructure. The later appears to be a better alternative.

In addition to milch cattle, an increase in the stock of plough bullocks was reported by the sample households. The stock of bullocks had increased from 11 in the pre-project period to 31 in Mar.' 13 . The beneficiaries attributed the improvement to CIF and ITDA support for purchase of bullocks and agriculture. The assignment of forest land to some households also acted as a catalyst.

In respect of sheep and goats, the stock situation remained more or less the same, although there is a change in the inter-district stock situation. There is a sharp improvement in Prakasam district, while there was a substantial decline in the number of sheep and goat in Kurnool district. The beneficiaries reported that the sudden decline in the number of sheep and goats in Kurnool was due to high mortality. Further, the households indicated that they keep selling their sheep and goats to meet family consumption in needs as well as for life domestic consumption. However, with the increase in market price for meat, the value of stock reported at 2 points of time shows a substantial increase. 
Table14. Change in Livestock Assets (Milch Animals): Sample

\begin{tabular}{|l|l|l|l|l|l|}
\hline S. No. & \multirow{2}{*}{ District } & \multicolumn{2}{l|}{ Before Velugu } & \multicolumn{2}{l|}{ Now with Velugu } \\
\cline { 3 - 6 } & & No. & Value in Rs. & No. & Value in Rs. \\
\hline 1. & Prakasam & 10 & 81375 & 18 & 234500 \\
\hline 2. & Guntur & 4 & 73500 & 22 & 479500 \\
\hline 3. & Kurnool & 6 & 105000 & 9 & 222250 \\
\hline 4. & Mahabubnagar & 1 & 17500 & 24 & 719250 \\
\hline 5. & Total & 21 & 277375 & 73 & 1655500 \\
\hline
\end{tabular}

Table15. Change in Livestock Assets (Bullocks): Sample

\begin{tabular}{|l|l|l|l|l|l|}
\hline S. No. & \multirow{2}{*}{ District } & \multicolumn{3}{l|}{ Before Velugu } & \multicolumn{2}{l|}{ Now with Velugu } \\
\cline { 3 - 6 } & & No. & Value in Rs. & No. & Value in Rs. \\
\hline 1. & Prakasam & 3 & 77000 & 21 & 645750 \\
\hline 2. & Guntur & 0 & 0 & 0 & 0 \\
\hline 3. & Kurnool & 4 & 105000 & 4 & 112000 \\
\hline 4. & Mahabubnagar & 4 & 105000 & 6 & 140000 \\
\hline 5. & Total & 11 & 287000 & 31 & 897750 \\
\hline
\end{tabular}

Table16. Change in Livestock Assets (Sheep and Goats): Sample

\begin{tabular}{|l|l|l|l|l|l|}
\hline S. No. & \multirow{2}{*}{ District } & Before Velugu & \multicolumn{2}{l|}{ Now with Velugu } \\
\cline { 3 - 6 } & & No. & Amount In Rs. & No. & Amount In Rs. \\
\hline 1. & Prakasam & 10 & 35000 & 94 & 341250 \\
\hline 2. & Guntur & 124 & 164500 & 127 & 495250 \\
\hline 3. & Kurnool & 253 & 105000 & 118 & 344750 \\
\hline 4. & Mahabubnagar & 44 & 78750 & 92 & 350875 \\
\hline 5. & Total & 431 & 383250 & 431 & 1532125 \\
\hline
\end{tabular}

Along with the ITDA, the project has contributed to a significant increase in household equipment including equipment used in agriculture such as electric motors, pump sets, ploughs, forest produce collecting equipment etc. In addition, the households also reported a significant increase in other household valuables such as TV, cell phones, two wheelers, small gold ornaments etc. While the value indicated may not be exact, there was certainly an increase in the household articles, both in terms of number and value.

Table17. Change in Livestock Assets (Equipment and Others): Sample

In Rs.

\begin{tabular}{|l|l|l|l|l|l|}
\hline S. No. & District & Equipment & Others \\
\cline { 3 - 6 } & & Before Velugu & Now With Velugu & Before Velugu & Now With Velugu \\
\hline 1. & Prakasam & 0 & 17500 & 0 & 17500 \\
\hline 2. & Guntur & 14000 & 249375 & 5250 & 326637 \\
\hline 3. & Kurnool & 3500 & 686700 & 1225 & 158375 \\
\hline 4. & Mahabubnagar & 67025 & 434875 & 24675 & 159722.5 \\
\hline 5. & Total & 84525 & 1388450 & 31150 & 662235 \\
\hline
\end{tabular}

\subsection{Change in Housing Status}

The project has also contributed to a significant change in the status of housing of the beneficiaries. Before Velugu, the Chenchus were living predominantly in semi-pucca and kutcha housing. With sustained ITDA support and with supplementary assistance provided by Velugu, the housing status has improved significantly. The percentage of households living in pucca houses has improved significantly and the proportion of those living in kutcha and semi-pucca housing has declined. However, a substantial proportion of sample beneficiaries $(25 \%)$ continued to live in kutcha houses.

Table18. Household Immovable Asset (House Type) (March 2009)

\begin{tabular}{|l|l|l|l|l|l|l|}
\hline S. No. & Category & Prakasam & Guntur & Kurnool & Mahabub-Nagar & Total \\
\hline 1. & None & 3 & 1 & 1 & 3 & 8 \\
\hline 2. & Kutcha & 13 & 5 & 6 & 3 & 27 \\
\hline 3. & Semi-pucca & 0 & 3 & 4 & 3 & 10 \\
\hline 4. & Pucca & 9 & 20 & 13 & 19 & 61 \\
\hline 5. & Total & 25 & 29 & 24 & 28 & 106 \\
\hline
\end{tabular}


Table19. Household Immovable Asset (House Type) (March 2013)

\begin{tabular}{|l|l|l|l|l|l|l|}
\hline S. No. & Category & Prakasam & Guntur & Kurnool & Mahabub-Nagar & Total \\
\hline 1. & None & 1 & 1 & 1 & 3 & 6 \\
\hline 2. & Kutcha & 13 & 4 & 5 & 2 & 24 \\
\hline 3. & Semi-Pucca & 0 & 1 & 1 & 2 & 4 \\
\hline 4. & Pucca & 11 & 23 & 17 & 21 & 72 \\
\hline 5. & Total & 25 & 29 & 24 & 28 & 106 \\
\hline
\end{tabular}

\subsection{Change in Income Status}

Notwithstanding the problems involved in quantifying household income based on the recall method, an attempt was made as part of the sample study to assess the change in the household income and the sources of change thereof. No attempt was however made to adjust the income with reference to the base year. The beneficiaries from all sample districts indicated a significant rise in household income, arising from agricultural labour, animal husbandry and MGNREGS. The change in income attributed to agriculture and animal husbandry are largely due to Velugu interventions. Even in respect of MGNREGS, the Velugu has facilitated the implementation of the scheme by making suitable advance payments. However, it is important to note that these are indicative estimates to suggest the direction of change in income over the last five years.

Table20. Total Annual Household Income from Different Sources: Sample (In Rs.)

\begin{tabular}{|l|l|l|l|l|l|l|l|l|}
\hline \multirow{2}{*}{ Category } & \multicolumn{3}{|l|}{ Prakasam } & \multicolumn{2}{|l|}{ Kuntur } & \multicolumn{2}{l|}{ Mahabubnagar } \\
\cline { 2 - 9 } & $\begin{array}{l}\text { Before } \\
\text { Velugu }\end{array}$ & $\begin{array}{l}\text { Now } \\
\text { with Velugu }\end{array}$ & $\begin{array}{l}\text { Before } \\
\text { Velugu }\end{array}$ & $\begin{array}{l}\text { Now } \\
\text { with Velugu }\end{array}$ & $\begin{array}{l}\text { Before } \\
\text { Velugu }\end{array}$ & $\begin{array}{l}\text { Now } \\
\text { with Velugu }\end{array}$ & $\begin{array}{l}\text { Before } \\
\text { Velugu }\end{array}$ & $\begin{array}{l}\text { Now } \\
\text { with Velugu }\end{array}$ \\
\hline Agriculture & 247625 & 693000 & 100625 & 124250 & 283500 & 651000 & 197750 & 656600 \\
\hline Agri. Labour & 64750 & 77000 & 324800 & 653625 & 95375 & 190750 & 169750 & 472500 \\
\hline EGS & 0 & 386750 & 0 & 507500 & 0 & 479500 & 0 & 498750 \\
\hline NTFP & 13125 & 0 & 45500 & 76475 & 233625 & 296625 & 84875 & 78750 \\
\hline Pension & 0 & 16800 & 0 & 21000 & 0 & 12600 & 0 & 4200 \\
\hline $\begin{array}{l}\text { Vidya } \\
\text { Volunteer }\end{array}$ & 0 & 21000 & 0 & 30625 & 0 & 0 & 0 & 0 \\
\hline $\begin{array}{l}\text { Animal } \\
\text { Husbandry }\end{array}$ & 0 & 24500 & 21000 & 176750 & 17500 & 35000 & 5250 & 21000 \\
\hline $\begin{array}{l}\text { Micro } \\
\text { Enterprises }\end{array}$ & 0 & 0 & 35000 & 236250 & 0 & 0 & 10500 & 122500 \\
\hline Others & 0 & 0 & 8750 & 21000 & 0 & 0 & 132125 & 307300 \\
\hline Total & 325500 & 1219050 & 535675 & 1847475 & 630000 & 1665475 & 600250 & 2161600 \\
\hline
\end{tabular}

\section{Perceived Benefits from CBOS}

An attempt was made to assess the perceived benefits derived and experienced by members from being in the CBOs promoted under the project and accessing the benefits received through them. A series of 8 FGDs were conducted in different project locations to ascertain the opinions of the sample members. In addition, an FGD was conducted at the meeting of the Maha Samakya in Mar.'13. In all 72 members participated in the FGD. The key benefits and problems perceived by the sample members are summarized in the following.

\section{Benefits PeRCEIVED}

\subsection{Exclusive Chenchu CBOs}

Establishment of exclusive Chenchu CBOs was perceived as a significant benefit from the project by the sample beneficiaries. Apart from promoting solidarity, the Chenchu CBOs were perceived to have contributed to unity and cooperation among the Chenchus. Further, the exclusive Chenchu CBOs provided a forum for discussing all issues without hesitation. In mixed SHGs, the Chenchus were reluctant to raise and discuss their issues. The Chenchus feel that the exclusive CBOs have promoted their cultural identity and brought them recognition at the policy level. Because of the homogeneous CBOs, the women were able to raise and articulate their issues and seek redress. The Chenchu Maha Samakya is a visible manifestation of their identity, strength and aspiration. 


\subsection{Access to Multiple Benefits}

All FGDs indicated that the exclusive CBO structure has enabled the Chenchus to access multiple benefits from the CBOs. Apart from CIF provided concessional rates of interest of 3\% and 6\%, the Chenchus opined that they were able to access bank loans, benefits from ITDA, MGNREGS and other agencies. As the CBOs are accepted by the line agencies as frontline delivery mechanisms, the agencies such as DWMA, ITDA and bankers were using them as channels to provide assistance. The MGNREGS routes its funds through the VOs partly as advance payments to enable the Chenchus to make use of the EGS fully. The ITDA also transfers its assistance for IGAs through the SHGs. The CIF for livelihoods, food security, health needs, housing and home needs is routed and recovered through the CBO structure. The Chenchus are able to access benefits of Abhayahastham and AABY by virtue of their being members of SHGs. Another significant benefit reported by the members was the improvement to their agricultural lands and undertaken with the support of NREGS. The members indicated that the land development activity has resulted in a larger proportion of land being brought under cultivation. These are tangible benefits perceived by the members from the CBOs established under the Chenchu development component of Velugu.

\subsection{Livelihood Assets}

A majority of the participants indicated that their livelihood asset base has improved significantly during the project period. Apart from improved access to land holdings, the Chenchus were provided assistance to set up bore wells, energized pump sets, procure minor agriculture equipment and meet their critical working capital needs with the support of ITDA and Velugu-CIF. Some of them were running small micro-enterprises such as petty eateries, petty tea shops and cool drink shops, seasonal pilgrim oriented shops (sale of coconut, flowers and leaves, agarbattis etc.,) sale of forest produce and wooden/bamboo handicrafts.

\subsection{Empowerment of Women}

The membership of CBOs as contributed to the status of women both in the household and outside. Within the household, the Chenchu women now enjoy a greater economic space. The fact that they can access internal loans, CIF loans and NREGS advance has provided them access to certain proportion of financial resources for their personal requirements. Within the household, women now play a more important role in decision-making in the areas of asset purchase and sale, running of IGAs, housing, education and health related expenditures. In addition, a significant proportion of women frequently visit banks, participate in capacity building and training sessions, attend MS and Maha Samakya meetings outside their own villages. They are able to interact and negotiate with bankers, government officials and others better than before. The improved mobility and negotiation skills have contributed in some measure to the empowerment of women. The members recalled that they were able to meet the Chief Minister of the state, the Principal Secretary, Rural Development, the CEO of SERP and other officials and present their problems without fear. According to them, these developments would not have been possible without the emergence of exclusive CBOs.

\subsection{Repayment Behaviour}

The members in the past were used to receiving subsidies and not repaying the loans received regularly. In fact, banks were totally reluctant to the Chenchus due to their poor repayment practices. The members participating in FGDs recalled that their repayment behavior has undergone a change. The members are now motivated and guided to repaying the different types of CIF loans as well as bank loans as per agreed schedule. The Chenchus attribute this change to the practices promoted in the CBOs and their realization of fact that the CIF is the community asset and will stay with the community perpetually. Further, the Chenchus now realize that they can access bank loans only if the repay the loans regularly. The observed change in the repayment culture is attributed to the Chenchu project.

\subsection{Distress Migration}

The FGD participants indicated that there was a significant reduction in distress migration in search of livelihood among them. Apart from the grain bank provided under the ITDA, the Velugu has enabled them to access CIF loans for promoting food security. The MGNREGS has significantly improved the wage employment during best part of the year and provided them additional income. As a result, most of the Chenchus do not go to West Godavari for paddy harvest, as a means of alternate livelihoods. 
More significantly, the AAY cards entitle all the Chenchu households to $35 \mathrm{~kg}$ of rice per month at a price of Rs.2/- per kg. Therefore, all the FGD participants admitted that the distress migration has declined significantly.

\subsection{Change in Living Standards}

The FGDs also indicated certain changes in the food habits, dress pattern, use of household articles and entertainment equipment. The participants indicated that they were in the habit of purchasing used clothes in the past. Now, the members reveal that they no longer buy used clothes. Several of them indicated that they buy new dress from the retail or wholesale shops from the nearby towns. Another change indicated was in the type of household utensils used. Most of them use steel vessels and plates for cooking and dining and a steel cupboard for storage. The use of earthenware for cooking is very rare. There is a big change in the use of entertainment equipment. A vast majority of the households were using TV with DTH facility, some reported to have been using CD players as well. Use of cell phones was on the increase even in the interior areas.

\subsection{Change in Health and Education}

Though a vast majority of the Chenchus continued to be illiterate, there is a growing realization that they should educate their children. The Chenchus are slowly being persuaded to send their children to Ashram schools/ residential hostels located in close proximity to their communities. The educational loans provided under CIF were also perceived to be a source of support for the households to send their children to higher studies. It was interesting to find that some Chenchu boys were studying B.P.Ed., and MBA. Some girls were being sent to nursing schools. In addition, there is an improvement in the housing status of the Chenchus. With the support of IAY and Indiramma housing programs, the proportion of semi-pucca houses built with ITDA support was reported to be on the decline. The number of pucca houses is on the increase.

\subsection{Alcohol and Tobacco Consumption}

The FGD participants, however, indicated that along with the livelihood changes, the consumption of alcohol by men has increased. The women complain that as a result of the additional income, improved access to loans and grain bank, the men spend a considerable amount on alcoholic liquors sold by illegal outlets (belt shops). The men also consume locally made alcohol out of Vippa flowers. The women also indicated that the men tend to spend a large amount on entertainment viz., cinema, CDs, TV equipment, VCDs etc. A considerable amount was also reported to be spent on cell phones. The saving habit has not improved with the incremental income. On the other hand, the men were indulging in avoidable expenditure. Some women also indicated that consumption of alcohol by women was not uncommon. This also needs to be checked. The consumption of betel leaf and nut and tobacco was also reported to have increased with additional sources of income. Udatala Edemma of Gayathri SHG, Garapenta village, Pullalacheruvu mandal, a participant at the Maha Samakya FGD indicated that she was spending only Rs.30/- per month on purchase of tobacco, when she was getting only a pension of Rs.200/-. Now, with the pension of Rs.500/- under Abhayahastham, the women admitted to consuming tobacco worth Rs.60/- per month. A similar perception was shared by several members. The use of tobacco products by men was also reported to have increased over the years.

\subsection{Debt Burden}

Along with the assets, the debt burden on the Chenchu households was reported to have increased as a result of larger access to CIF and bank loans. Though there was a decline in high cost borrowing, the total debt burden on the households was reported to have increased. A part of the bank loan and internal loans were reported to have been used by most households for consumption purposes including family ceremonies and life cycle rituals. Thus, the debt burden seems to have increased at a higher rate than the assets acquired through CIF and other loans. This points to the need for improving the utilization of borrowed funds.

\section{SUMMARY}

The focused efforts made by the project through the Chenchu Development Plan had positive effect. A total of 18,372 Chenchu households were brought into 1,698 SHGs. The SHGs were federated into exclusive Chenchu VOs (147) and VOs into Chenchu MSs (17). An apex federation called the Maha Samakya was established federating the 17 MSs into a collective body. A substantial amount of Rs.7.85 crore was allocated to the Chenchus under the CIF to meet the livelihood and other 


\section{B. Seetharamaiah}

requirements of the Chenchus (food security, health, education, home needs, NTFP and procurement and agriculture). The Community Investment Fund (CIF) covered 50\% of the total households at an average rate of over Rs.15,000/- per household. In addition, 166 SHGs were bank linked up to Mar. '13 for a total amount of Rs.2.50 crore. Dedicated implementation structures were put in place to implement the Chenchu development activities in the 17 mandals. A vast network of Community Activists (CAs) were identified, trained and utilized for nurturing the SHGs. A Community Resource Person (CRP) approach was used to build the capacities of the SHGs and federations for selfmanagement. A wide range of activities were taken up to converge the Chenchu development plan with on-going efforts of Integrated Tribal Development Agency (ITDA), District Rural Development Agency (DRDA), MGNREGS and other agencies to bring about sustainable changes in the livelihoods of Chenchus.

The household level changes observed appeared very significant. There was a significant improvement in the housing status as well as livelihood assets of the Chenchu household. A large number of households came to possess milch cattle and small ruminants, largely facilitated by CIF and bank loans. The ITDA support dovetailed resulted in a larger proportion of agricultural land being brought under cultivation. The dependence of Chenchu household on traditional source of borrowing had declined. Even more significant was the decline in distress migration. There was a significant improvement in the income levels of the Chenchu households. However, personal habits such as alcohol and tobacco consumption and expenditure on rituals continued to be very high. A close supervision and follow-up appeared necessary to prevent asset dispossession. The community institutions of Chenchus need to be nurtured further to ensure that this primitive tribal group is completely mainstreamed into the socio-economic life of the region.

\section{REFERENCES}

[1] APMAS, SHG Federations in India -A Publication of APMAS ,CESS ,India 2007

[2] APMAS, Status of SHG federations in Andhra Pradesh, APMAS, Hyderabad ,India 2007

[3] CESS, Andhra Pradesh Rural Poverty Reduction Project (APRPRP), CESS, Hyderabad.

[4] CESS, Report of Baseline survey of APDPIP, CESS, Hyderabad

[5] CESS, Report of Baseline survey of APRPRP, CESS, Hyderabad

[6] Joseph sybimon, Sustainability of micro enterprises run by self-help groups in Kerala, Doctoral dissertation to Gandhi gram Rural University, Dindigul, 2007.

[7] MYRADA, Assessment of community based institutions, MYRADA, Bangalore.

[8] MYRADA, Guidelines for financing self-help groups, MYRADA, Bangalore.

[9] MYRADA, self-help groups- The concept, MYRADA, Bangalore. 